\title{
CAMBRIDGE Goethe contra Newton
}

Polemics and the Project for a New Science of Color DENNIS L. SEPPER

This book explains the background and rationale of the German poet Johann Wolfgang von Goethe's notorious attack on Isaac Newton's classic theory of white light and colours. As simultaneously poet, scientist, historian and philosopher, Goethe is seen to anticipate important twentieth-century research not only in the history and philosophy of science, but even in colour science itself.

$$
256 \text { pp. } 1988 \quad 052134254 \quad 6 \quad \text { s27.50 net }
$$

\section{Power and Penury}

Government, Technology and Science in Philip II's Spain

\section{DAVID GOODMAN}

David Goodman's unique and deeply-researched book is a reconsideration of Philip II's relations with technology and the sciences, showing the Crown's considerable involvement in shipbuilding, military engineering, mining, medicine and the occult.

\section{8 pp. $1988 \quad 0 \quad 521305322 \$ 30.00$ net}

\section{Now in paperback}

\section{The Other World}

Spiritualism and Psychical Research in England 1850-1914

\section{JANET OPPENHEIM}

This acclaimed and readable book examines the public fascination with spiritualism and psychical research in the 19th and early 20th Century, when many embraced it as a surrogate religion or as the science of the future.

'...the picture it draws is one of extraordinary interest.' The Times Literary Supplement 503 pp. 1988 o $52134767 x \quad \& 12.95$ net

Now in paperback

\section{The Birth of History and Philosophy of Science}

Kepler's A Defence of Tycho against Ursus with Essays on its Provenance and Significance

\section{NICHOLAS JARDINE}

'Jardine's book is rich in epistemological and historiographical issues, bold and stimulating in its speculations, and detailed in its use of evidence... few will deny the substantial contributions made by its author to our understanding of the origin of Kepler's advanced conceptions ...'

320 pp. O 52134699 I Paperback s9.95 net

\section{Astronomical Centers of the World}

\section{K. KRISCIUNAS}

Astronomy's development has been fostered by many observatories, but at any one time in its long history there has usually been one outstanding centre whether it be Tycho Brahe's observatory of Hven, the Kitt Peak National Observatory or the new satellite stations. This book is an introduction to the influential observatories whose workers have shaped astronomy through the ages.

$$
336 p p \text {. } 1988 \quad 0521302781 \text { s17.50 net }
$$

For further details of Cambridge books on the History of Science, please urite to Sbelby Howe at the Cambridge address.

\section{Cambridge University Press}




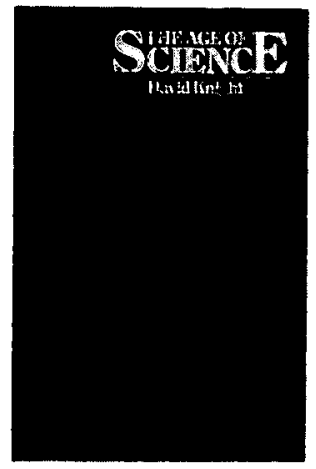

The Age of Science

The Scientific World-View in the Nineteenth Century

\section{DAVID KNIGHT}

David Knight tells the story of the most formative period of scientific discovery-the nineteenth century - when scientific ideas dominated thought and arguments became characteristic of its study.

'There is much to admire about this book ... the scholarship on which it lightly rests is solid and up to date...' The Scientist

'Readable and entertaining.' New Scientist

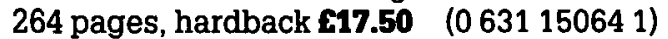
paperback $\$ 7.95 \quad(0631161767)$

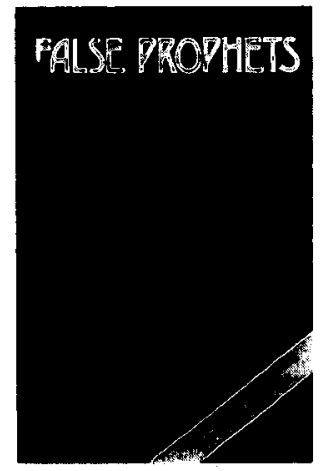

\section{False Prophets}

Fraud and Error in Science and Medicine Revised Edition

\section{ALEXANDER KOHN}

In this wide-ranging study of the motives, conditions and pressures that make fraud possible in science and medicine, Alexander Kohn unearths lesserknown incidents alongside famous frauds like the Piltdown man. Now revised, new evidence is applied to original case studies and an additional chapter raises critical questions.

$\therefore$.. fascinating consideration of all aspects of falsification within the sciences.' Times Literary Supplement paperback $67.95 \quad(0631162372)$

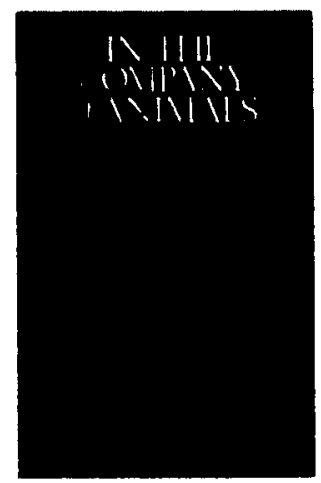

\section{In the Company of Animals}

\section{A History of Human-Animal Relationships JAMES SERPEIL}

'Full of fascinating comments ... thoughtful and well-researched.' Desmond Morris, BBC Wildlife 'Lively and entertaining.' The Independent

'Rousing and valuable.' The Observer

224 pages, hardback $\$ 14.95 \quad(0631$ 14536 2)

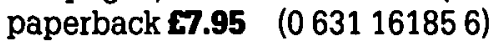

\section{Basil Blackwell}

108 Cowley Road, Oxford OX4 1JF

Suite 1503, 432 Park Avenue South, New York NY 10016.

Toll-free ordering: $1-800-638-3030$ (USA) 


\section{THE BRITISH SOCIETY FOR THE HISTORY OF SCIENCE}

Membership of the Society, which normally includes a subscription to The British Joumal for the History of Science, is open to all persons approved by the Council of the Society and elected at an ordinary meeting. The annual subscription for the membership year 1988 is $£_{1} 6.00(\$ 32.00)$ or $£ 8.00$ $(\$ 16.00)$ for associate membership, which includes students at centres of higher education. There is an Introductory Offer for ordinary members who pay $£_{11}$.00 (\$22.00) for the first year. Applications for membership should be made on a form which is available from the Society's Executive Secretary at the address below.

Meetings: The Society mounts an ambitious programme of meetings. The pattern is flexible, the only fix ture being the three day summer meeting, held at a different British University or Polytechnic each year. About four other meetings, lasting for between one and three days, are held during the year, sometimes devoted to a clearly-defined theme or an important anniversary, and often arranged in conjunction with other scholarly societies.

The British Joumal for the History of Science is the official organ of the Society. All correspondence on the contents of the Journal should be addressed to the Editor, Dr David Knight, Department of Philosophy, University of Durham, 50 Old Elvet, Durham DH $13_{3 \mathrm{HN}}$ England.

Books for review should be sent to the Reviews Editor, Dr John Hendry, 58 Canfield Gardens, London NW6 ${ }_{3} \mathrm{~EB}$.

Advertising: Contact the Advertising Department, Blackwell Scientific Publications, Osney Mead, Oxford, OX2 oEL. Fax no. (0865) 721205.

Other publications: BSHS Monograph Series is designed to allow the publication of monographic studies in the history of science quickly and cheaply. All correspondence on the subject of monographs, and any new suggestions for titles, should be sent to the Series Editor, Dr J. G. Smith, Department of History, University of Loughborough, Loughborough, Leics LE I I 3 TU, England. Monographs are available to members at a special price, post-free from the Society's Executive Secretary. Non-members may obtain them through bookshops, or post-free from the Executive Secretary. Titles are as follows:

2. The Letters of Georges Cuvier: A Summary Calandar. Ed. by Dorinda Outram. 1980. $£ 4.50 / \$ 9.00$ (£3.50/\$7.00 to members).

3. Rationality and Ritual: The Windscale Inquiry and Nuclear Decisions in Britain. By Brian Wynne. $£ 7.00 /$ $\$ 14.00\left(£ .5 .00 / \$_{10.00}\right.$ to members).

4. The Royal Society and Its Fellows 1660-1700: The Morphology of an Early Scientific Institution. By Michael Hunter. $£ 9.00 / \$ 18.00$ ( $£ 6.5 \% / \$ 13.00$ to members).

5. Francis Bacon's Natural Philosophy: A New Source. A Transcription of Manuscript Hardwick $72 A$ with Translation and Commentary. By Graham Rees, assisted by Christopher Upton. $£ 7.90 / \$ 15.50$ (£5.60/ $\$ 11.50$ to members).

6. Archives of the British Chemical Industry, 1750-1914: A Handlist. By Peter J. T. Morris and Colin A. Russell (available Autumn 1988).

List of theses: Every December, the Society publishes a full list of current theses in history of science in British universities. This is available free to members, and at $£_{2.00}(\$ 4.00)$ to non-members on request to the Executive Secretary. Standing orders are accepted from members or non-members who wish to receive the list regularly.

The Society's Newsletter, an informal publication edited by Dr Mari Williams, Business History Unit, Lionel Robbins Building, Io Portugal Street, London WC2A ${ }_{2} \mathrm{HD}$, appears in January, May and September each year. It is free to members, $£ 4.50(\$ 9.00)$ for institutions and non-members.

All the administrative business of the Society is handled by The Executive Secretary, Wing Commander G. Bennett, 3 I High Street, Stanford in the Vale, Faringdon, Oxfordshire $\mathrm{SN}_{7} 8 \mathrm{LH}$. 


\section{September 1988}

273 Colin A. Russell: Presidential Address: 'Rude and Disgraceful Beginnings': A View of History of Chemistry from the Nineteenth Century

295 Yushi Ito: Hooke's Cyclic Theory of the Earth in the Context of Seventeenth Century England

3 I 5 Steve Sturdy: Biology as Social Theory: John Scott Haldane and Physiological Regulation

34 I Roland Bechmann: About some Technical Sketches of Villard de Honnecourt's Manuscript. New Light on Deleted Diagrams: An Unknown Drawing

$362 \quad$ Book Reviews

387 Books Received

\section{B S H S \\ THE BRITISH \\ SOCIETY FOR \\ THE HISTORY \\ OF SCIENCE}

Published for The British Society for the History of Science

by Blackwell Scientific Publications

Oxford $\cdot$ London $\cdot$ Edinburgh $\cdot$ Boston $\cdot$ Palo Alto $\cdot$ Melbourne

(C) The British Society for the History of Science 1988

Printed in Great Britain at the Alden Press, Oxford 